\title{
Inflammation in Alzheimer's disease: relevance to pathogenesis and therapy
}

\author{
Elina Zotova* ${ }^{* 1}$, James AR Nicoll, ${ }^{1,2}$, Raj Kalaria ${ }^{3}$, Clive Holmes ${ }^{1,4}$ and Delphine Boche
}

\begin{abstract}
Evidence for the involvement of inflammatory processes in the pathogenesis of Alzheimer's disease (AD) has been documented for a long time. However, the inflammation hypothesis in relation to $A D$ pathology has emerged relatively recently. Even in this hypothesis, the inflammatory reaction is still considered to be a downstream effect of the accumulated proteins (amyloid beta (A $\beta$ ) and tau). This review aims to highlight the importance of the immune processes involved in AD pathogenesis based on the outcomes of the two major inflammation-relevant treatment strategies against $A D$ developed and tested to date in animal studies and human clinical trials - the use of anti-inflammatory drugs and immunisation against $A \beta$.
\end{abstract}

\section{Inflammation in Alzheimer's disease and the inflammation hypothesis}

In addition to amyloid beta $(A \beta)$ and tau protein aggregates, the presence of immune-related antigens and cells around amyloid plaques in the brains of patients with Alzheimer's disease (AD) has been reported since the 1980s [1-3]. These initial observations brought about changes to the previously assumed view of the brain as an immunologically isolated organ. In the 1990s, additional findings of activated complement factors, cytokines and a wide range of related receptors in the brain of $\mathrm{AD}$ patients led to the concept of neuroinflammation (inflammation within the central nervous system $(\mathrm{CNS})$ ), which suggests that immunological processes in the brain are likely to be involved in the pathology of degenerative diseases of the CNS. Table 1 lists signs of an altered immune response reported in AD patients.

*Correspondence: elina.zotova@soton.ac.uk

'Division of Clinical Neurosciences, School of Medicine, University of

Southampton, Mailpoint 806, Level D, South Pathology Block, Southampton

General Hospital, Southampton, SO16 6YD, UK

Full list of author information is available at the end of the article
The role of aggregated proteins in the pathology of $A D$ had to be re-considered to account for these observations. The inflammation hypothesis emerged relatively recently, when it became clear that the observations of altered immune processes in AD could not be ignored. Neuroinflammation is still considered to be a downstream consequence in the amyloid hypothesis, with $A \beta$ amyloid within the CNS bringing about activation of microglia, initiating a pro-inflammatory cascade that results in the release of potentially neurotoxic substances, including cytokines, chemokines, reactive oxygen and nitrogen species, and various proteolytic enzymes, leading to degenerative changes in neurons [4-7]. It has also been suggested that activation of microglia may lead to phosphorylation of tau and formation of neurofibrillary tangles (NFTs) [8-10]. However, the exact role of inflammation in the pathology of $\mathrm{AD}$ and its mechanisms in terms of the cells involved - microglia, astrocytes and $\mathrm{T}$ lymphocytes - are still debated.

The inflammation hypothesis is also supported by epidemiological retrospective observations that patients with rheumatoid disease who are on long-term antiinflammatory therapy have a lower prevalence of $\mathrm{AD}$ [11-15]. Other largely observational studies have also supported the concept that anti-inflammatory approaches may be protective against the development of $\mathrm{AD}[16,17]$. Furthermore, transgenic animal studies and human trials have demonstrated that treatment with nitric oxidereleasing non-steroidal anti-inflammatory drugs (NSAIDs) can reduce and/or prevent the AD pathology (reviewed by McGeer and McGeer [18]). It has also been shown that a certain drug with anti-inflammatory properties (CNI-1493) suppresses amyloid pathology and improves memory performance in transgenic mice [19]. Despite these findings, however, several prospective anti-inflammatory strategies against disease progression in subjects with established $\mathrm{AD}$ have failed to show convincingly positive results (see the 'Current treatment strategies based on the inflammation hypothesis' section below). Although these effects did not reach significant levels in large human cohorts [20], interest in the inflammatory processes of $\mathrm{AD}$ pathology has persisted [21,22]. One particularly interesting aspect of these studies was that 
Table 1. Signs of altered immune response in Alzheimer's disease patients and relevant references

\begin{tabular}{|c|c|}
\hline Signs of altered immune response & References \\
\hline Presence of HLA-DR or LFA-1 (leucocyte function-associated antigen) positive reactive microglia around senile plaques & {$[1,2,35,37,40]$} \\
\hline Increased hippocampal gene expression of MHC II in AD compared to high-pathology controls & [95] \\
\hline Elevated brain levels of IL-1 $\beta$ and S-100 & [3] \\
\hline Presence of activated elements of classical complement pathway (C1q, C3d, C4d) within dystrophic neurites, NFTs and/or A $\beta$ plaques & {$[34,36,96]$} \\
\hline Up-regulated mRNA levels of complement elements C1q and C9 in AD brain & [97] \\
\hline Strong IL-6 immunoreactivity around plaques and large cortical neurons & [38] \\
\hline Low levels of TNFa in brain areas with AD pathology & [39] \\
\hline Increased levels of TNFa in sera of severe stage AD patients & [98] \\
\hline Increased levels of intracellular neuronal IL10, IFNY and IL12 in AD patients compared to age-matched controls & [99] \\
\hline Correlations between Mini Mental State Examination scores and in vivo imaging marker [11C](R)PK11195-PET of activated microglia in AD patients & [42] \\
\hline
\end{tabular}

$A \beta$, amyloid beta; $A D$, Alzheimer's disease; IFN, interferon; NFT, neurofibrillary tangle.

(at least in animal models) the observed beneficial action of anti-inflammatory drugs was not necessarily attributed to down-regulation of inflammatory processes. Instead, activation of microglia via a route that enhances its phagocytic activity against $A \beta$ was suggested [23].

The inflammation hypothesis also suggests another approach to sporadic AD and associated risk factors for investigation - polymorphism of genes related to induction and regulation of inflammatory processes. Initial studies suggested a role for specific cytokine polymorphisms for example, in the genes encoding IL-1 and TNF $\alpha$ $[24,25]$ - with evidence that IL-1 polymorphism may be associated with differing degrees of microglial activation in $\mathrm{AD}$ [26]. However, a meta-analysis of genetic influences in $\mathrm{AD}$ has not supported the initial findings of cytokine gene variation as a risk factor for $\mathrm{AD}$, but has instead emphasised the over-riding importance of the $A P O E$ gene polymorphism as the major genetic risk factor [27]. Although many mechanisms for the role of apolipoprotein $\mathrm{E}$ (APOE) in AD pathogenesis have been suggested [28], the key mechanism remains unclear. Of particular interest to the inflammation hypothesis is the finding that APOE $\varepsilon 4$ carriers with $\mathrm{AD}$ have more marked microglial activation [29].

Research into the role of inflammation in AD is driven by questions similar to those posed for $A \beta$ and abnormal tau accumulation. Can neuroinflammation be the cause of $\mathrm{AD}$ ? Are the inflammatory processes in $\mathrm{AD}$ contributing to the disease pathology? Alternatively, are they merely the consequence of the disease, initiated and driven by the neurodegeneration? Does inflammation act as a harmless bystander in the disease course? Can the immune processes of the brain be harnessed to fight against the disease pathology?

Inflammation as the sole cause of $\mathrm{AD}$ is usually considered as unlikely on the basis that peripheral systemic disorders rarely start with inflammation - there is an initial challenge that is required to stimulate an immune (or inflammatory) response [30]. However, it should be noted that being a response to an insult rather than an insult itself, inflammation plays an important role in the reaction of an organism to this insult, with potentially damaging and sometimes fatal consequences (for example, in allergy). Autoimmune diseases can affect the CNS (for example, paraneoplastic syndromes, multiple sclerosis) but there is little evidence to suggest that $\mathrm{AD}$ falls into this category.

With respect to whether inflammatory processes in $\mathrm{AD}$ contribute to the disease pathology, a lot of evidence has accumulated suggesting that inflammation can contribute to the $\mathrm{AD}$ process and exacerbate the course of the disease. It is still unclear exactly how inflammation acts on the diseased brain, as most of the observations about the mechanisms of its action are based on animal models. However, the supportive evidence for inflammation being a contributor to the disease process is as follows. First, the cognitive state of $\mathrm{AD}$ patients who also have shortterm peripheral infection show signs of sudden decline in cognitive state, and rarely return to the previous level even after recovery from the infection [31]. Second, community-based studies suggest that plasma levels of inflammatory proteins, including cytokines, are increased before clinical onset of dementia, including $\mathrm{AD}$ [32], which may be exacerbated by the presence of atherosclerosis [33]. Third, observed signs of inflammation in the brain of $\mathrm{AD}$ patients are comparable to those seen in peripheral inflammatory reactions and are likely to have a strong cytotoxic effect on neurons [5,30]. Fourth, signs of inflammation are particularly localised in the brain areas affected by $\mathrm{AD}$ pathology and co-localise with plaques and tau deposits [1,2,34-40]. Fifth, high pathology controls (individuals who have $A \beta$ and tau aggregates at levels similar to AD patients, but do not develop dementia) show lower signs of inflammation [41]. Sixth, Mini 
Mental State Examination scores of AD patients correlate with the level of cortical microglial activation as observed from in vivo imaging studies [42].

From these observations, inflammation could contribute to the course of AD in two ways. Firstly, as an initial innate immune response to the changes in the $\mathrm{AD}$ brain. In the periphery, the innate immune system generates a non-specific response to an invading pathogen or a cell stress stimulus as a general first-line defence mechanism. Inflammation is part of this response, involving signalling via cytokines and via activation of the complement system to recruit the immune cells to the site of stress. In the periphery, this response is also often referred to as an acute, strong, but short-lived immune reaction. In the context of $\mathrm{AD}$, association of microglia - the immune system cells of the CNS - with plaques and NFTs has been observed, suggesting involvement of innate immunity in the reaction to the AD-related stimuli. Observations of acute-phase inflammatory proteins alongside cytokines and chemokines associated with plaques and tangles in $\mathrm{AD}$ have been reported, suggestive of multiple ways of interaction between these inflammatory mediators [5]. The presence of elements of the complement system and membrane attack complex C5b-9, in particular, has been reported to correlate highly with the level of synaptic loss [41]. This engagement of the complement system has not been observed in the brains of high pathology controls, contributing to evidence of the involvement of acute mediators in AD. The C5b-9 complex is known to be very potent at killing or damaging neurons through signalling for production of various cytokines and other complement elements [30]. However, most studies refer to inflammation in $A D$ as weak and non-specific. This is explained on the basis of the presence of multiple mechanisms that regulate inflammatory reactions within the brain and minimise them [43]. Nevertheless, long exposure to ongoing inflammation signalling, even at low levels, can bring about gradual neurodegeneration that might be more difficult to stop or reverse than acute inflammatory episodes observed in peripheral disorders [30].

Secondly, the low-level ongoing inflammation in AD contributing to the course of the disease can be a sign of impaired adaptive immune responses leading to chronic inflammation. In the periphery, an innate immune response is followed by a switch to an adaptive response with generation of antibodies and overall down-regulation of acute pro-inflammatory signalling. The functions of the adaptive immune response include induction of more specific and stronger defence mechanisms against abnormal stimuli, and engagement of memory $\mathrm{T}$ cells that can recognise and eliminate the same stimulus more quickly and efficiently if it is encountered again in the future. The important feature of this type of response is to be able to recognise 'non-self' antigens and distinguish them from 'self'. In the context of $\mathrm{AD}$ pathology, $\mathrm{A} \beta$ plaques and NFTs persist, accompanied by ongoing inflammation over a long period of time, during which the disease progresses. It is suggested, therefore, that after induction of the initial immune response, when plaques and tangles are recognised as invading stimuli, transition to the adaptive immune response and the mechanism of recognition of plaques and tangles as persisting stress stimuli is impaired. With respect to microglia in AD, this effect is reflected by their inability to transit from an initial classic state (also referred to as pro-inflammatory or Th1induced) to an alternative (anti-inflammatory or Th2induced) immune response. Impaired activation of microglial Toll-like receptors in AD brain has also been suggested [44-46]. The result is that phagocytic activity as well as the neuroprotective function of microglia are impaired [47].

The type of inflammation in the $\mathrm{AD}$ brain is not well defined and is often blamed on 'dysfunctional' or 'malactivated' microglia [48]. The exact profile of these microglia has not yet been well characterised [4], but the description is often based on observation of a single marker or a dystrophic and apoptotic appearance of the cells [48-50].

Some studies report the presence of auto-antibodies against $A \beta$ in older people [51], and possible involvement of $\mathrm{T}$ and $\mathrm{B}$ cells in the $\mathrm{AD}$ process $[52,53]$. However, conclusive positive evidence for direct involvement of antibody-mediated response in $\mathrm{AD}$ has not yet been presented [30].

One could also suggest that inflammation observed in the brains of $\mathrm{AD}$ patients is merely a consequence of the disease, pointing to an inability of microglia to clear evergrowing neuronal debris due to extensive neurodegeneration and synaptic loss. Impaired recruitment of monocytes from the periphery to the site of the disease in AD brain has been suggested in this respect and demonstrated using animal models [54-56].

The phagocytic profile of microglia that is often referred to in $\mathrm{AD}$ brain is generally non-aggressive, aiming at clearing the damage/debris with minimal further damage to the surrounding tissue, leading to the question: can inflammatory activity in AD brain have a neutral or even beneficial role? However, another perspective comes from studies using a model of neurodegeneration - the ME7 mouse model of prion disease [57]. These studies suggest that microglia in the context of a neurodegenerative disease, although generally in an anti-inflammatory state, are 'primed' to switch quickly into an aggressive profile should the opportunity arise. Such an opportunity may be a peripheral infection, as demonstrated in this model [58].

Mixed and often contradictory findings with respect to inflammation in $\mathrm{AD}$ indicate the complexity and 
multi-functional role of the immune system. It became apparent that inflammation in the CNS, as in the periphery, is a mixture of both destructive and rebuilding processes. The balance between these processes determines the overall integrity of the tissue or the whole organism [59]. Therefore, inflammation should not be viewed as wholly detrimental or beneficial in $A D$. Understanding of the whole spectrum of the immune processes involved is necessary to find an optimal solution for the prevention or treatment of the disease.

The possibility of harnessing immune processes to direct the system towards clearance of the disease features has become an actively researched topic of AD. Much AD research is now aimed at modulation of the immune system to direct it away from microglial activation that is pro-inflammatory (or malactivated) towards a more controlled productive and phagocytic antibodymediated immune response [60].

In summary, the pathological changes associated with $\mathrm{AD}$ as described above should not be considered in isolation. It is more likely that their cumulative action results in disruption of the normal work of the CNS through damage to neurotransmitter systems, neuronal dysfunction and death.

\section{Current treatment strategies based on the inflammation hypothesis}

Two main treatment approaches addressing inflammatory processes in $\mathrm{AD}$, but from different perspectives, have been investigated so far. The use of anti-inflammatory drugs aims to down-regulate the inflammation in $\mathrm{AD}$ brain for a potential beneficial effect, whereas the immunotherapy approach aims to harness the immune system and direct it against the pathological features of the disease, mainly $\mathrm{A} \beta$ deposition. The advances in, and limitations of, both approaches are discussed below.

\section{Anti-inflammatory drugs}

As mentioned above, retrospective studies of patients who were on NSAIDs long-term showed that these patients had a lower prevalence of AD. These observations have generated interest in anti-inflammatory strategies for AD. The approach was tried in APPSW and APP-PS1 transgenic mouse models of AD using nitric oxide-releasing NSAIDs [23,61]. Both studies showed that treatment with these drugs reduces and/or prevents AD pathology in the animals. The involvement of microglia was suggested, but the results were contradictory, reporting decreased microglial activation in the APPSW model [61] but surprisingly raised levels of activated microglia in the APP-PS1 model [23]. An effect of NSAIDs in decreasing secretion of $A \beta$ was observed in cultured cells [62]. However, the mechanism of action of the NSAIDs is not understood. Epidemiological studies show various degrees (up to 50\%) of beneficial effect from the use of NSAIDs on the onset of the disease and dementia, with increased duration of drug use having a positive effect by reducing the relative risk of $\mathrm{AD}$ $[16,17,20]$. However, the results from randomized controlled clinical trials did not show any beneficial effect (reviewed by McGeer and McGeer [18]). Conventional NSAIDs can also cause undesirable side-effects (for example, gastrointestinal ulceration) [20].

\section{Immunisation}

Driven by the amyloid hypothesis and by observations of microglia surrounding plaques in $\mathrm{AD}$, but being unable to clear the plaques in animal models of $\mathrm{AD}$ and in human post-mortem observations, the immunisation approach has emerged. The idea of modifying the immune system and directing it towards effective clearance of plaques has generated a lot of interest.

\section{Animal studies}

In animal models, immunotherapy has been reported to prevent the formation of and to clear existing $A \beta$ deposits, and to remove dystrophic neurites [63-75]. The first reported immunisation study used PDAPP transgenic mice and synthetic human A 342 peptide as the antigen [63]. The animals developed a high antibody response (titre 1:10,000). Complete prevention of amyloid and neuritic pathology was achieved in mice immunised at 6 weeks of age, and extensive plaque clearance was achieved in older mice immunised at 11 months of age. Older immunised animals also showed A $\beta$-containing cells with an activated microglial phenotype, suggestive of Fc receptor-mediated clearance of A 342 . Significant reduction in neuritic pathology as well as reactive astrocytosis were also observed in the older immunised group when compared to untreated controls.

This work was followed by similar studies using $\operatorname{Tg} 2576$ and TgCRND8 APP transgenic mice. Active immunization in these models showed various levels of plaque clearance (up to 50\%), significant behavioural improvements in older animals, and prevention of cognitive deficit in a younger group $[64,66]$.

Administration of antibodies against A $\beta$ (m266, 3D6, $10 \mathrm{D} 5, \mathrm{PabA} \beta 1-42)$ directly into the brain or via the periphery (passive immunisation) in PDAPP transgenic mice also showed findings similar to active immunisation with regard to reduction of AD-like pathology through clearance of $A \beta$ plaques and improved memory and learning performance $[65,67,69,70]$. In one study, however, memory deficits were reversed even without alteration to $\mathrm{A} \beta$ burden [70].

These studies posed questions about possible mechanisms of plaque clearance. Amyloid-antibody complex 
interaction with microglial Fc receptors was suggested as one possible mechanism [65]. A non-Fc-mediated mechanism of direct plaque destruction with $\mathrm{F}\left(\mathrm{ab}^{\prime}\right) 2$ antibody fragments that lack the Fc component was also proposed [69]. However, the role of Fc receptor-mediated phagocytosis in plaque clearance after immunotherapy was questioned when $A \beta$ clearance was observed in actively immunised phagocytosis-deficient (FCR-/-) APP mice at levels similar to FcR non-deficient APP mice [71]. Equally, the ability of $\mathrm{F}\left(\mathrm{ab}^{\prime}\right) 2$ fragments to activate microglia and remove amyloid fibrils was questioned when another study showed that these fragments fail to activate microglia and are less effective than IgG antibodies at clearing plaques [76]. A two-step mechanism of plaque removal using anti-A $\beta$ antibodies was proposed: an initial rapid decrease in $A \beta$ deposition 24 hours after antibody administration, followed by microglia-dependent removal 3 days after antibody injection [72]. A 'sink' mechanism was also proposed in which monoclonal antibody to $A \beta$ may attract $A \beta$ across the blood-brain barrier from the brain into the periphery [67].

Although these studies showed that immunisation with $A \beta$ was successful in animals, the models used, however, did not reflect the full pathology of AD (that is, they lacked NFTs or substantial neurodegeneration despite $\mathrm{A} \beta$ deposition). It was not clear from these studies if generation of anti-A $\beta$ antibodies and removal of amyloid would show improvement of cognition in humans. Safety issues were also highlighted with respect to the acceptable and effective levels of antibodies that can be used in animals versus humans, the preference of the active over passive immunisation approach, and the exact mechanism of action of the vaccine [77]. The antibody levels in animals had to be quite high to reach the desired effect of $A \beta$ removal. The concern was whether sufficiently high levels of anti-A $\beta$ antibody can be safely produced in humans. A detailed mechanism of action initiated by the immunotherapy was also not established.

Despite these concerns and unanswered questions, the immunisation approach progressed to human clinical trials (see the 'Human clinical trials' section below). Following the halting of the active immunisation phase IIa trial (conducted by Elan Pharmaceuticals) due to an inflammatory side-effect in a subset of patients, more recent animal immunisation studies have been focusing on induction of a controlled immune response to AD pathology that avoids strong pro-inflammatory reaction. A necessity for a model that would reflect the full pathology of the disease led to the generation of the triple transgenic mouse model $(3 \times \mathrm{Tg}-\mathrm{AD})$, which shows $\mathrm{A} \beta$ deposition as well as tangle formation, synaptic degeneration and behavioural impairments [78,79]. Recent immunisation studies using this model showed that intrahippocampal administration of $\mathrm{A} \beta$ antibodies clears or prevents plaque formation as well as clears early phosphorylated tau [80]. The same group further investigated the effect of active and passive $A \beta$ immunisation and demonstrated the importance of clearing both soluble $A \beta$ and soluble tau for the improvement of cognitive performance [81]. The latest active immunisation animal study in the Tg2576 model aimed to show that using non-toxic, non-fibrillogenic forms of $A \beta$ together with an adjuvant that promotes a humoral, rather than a cell-mediated, response is effective in removal of $\mathrm{AD}$ pathology without adverse inflammatory effects and microhaemorrhages [75]. This study also confirmed that immunisation is more effective at early stages of the disease. The same group tested active immunisation with different $A \beta$ species in young lemur primates in order to evaluate the antibody response and choose the most efficient peptide and adjuvant for further studies in old lemurs [82]. Tau-specific immunisation in various models of tauopathies is also underway [83].

\section{Human clinical trials}

Clinical trials testing the active immunisation approach against $A \beta 42$ were set up by Elan Pharmaceuticals. The first multicentre randomised multiple-dose double-blind human trial (phase I) was designed to assess the antigenicity, safety and tolerability of the developed treatment, and was performed between April 2000 and June 2002. Eighty mild to moderate stage AD patients 85 years old or less were recruited in the south of the United Kingdom. Of the recruited patients, 64 received multiple doses of 50 or $225 \mu \mathrm{g}$ of A $\beta 42$ peptide in combination with the QS21 adjuvant (AN-1792), and 16 received adjuvant alone (placebo). Four injections were administered at weeks $0,4,12$, and 24 , with permission to administer additional injections at weeks 36, 48, 60 and 72. Patients were assessed every 2 to 3 weeks. At the end of the study, it was reported that the treatment was well tolerated. Approximately 25 to $50 \%$ of the patients who received the active treatment developed a positive immune response to AN-1792 [84].

In June 2001, a further study was initiated with a larger patient sample (phase IIa); 375 patients were recruited in Europe and the USA, of which 300 were to receive multiple doses of $225 \mu \mathrm{g}$ AN-1792. This trial was halted after several months as 18 patients developed aseptic meningoencephalitis [85].

The clinical report from the phase IIa study showed that most of the patients who developed this inflammatory side-effect were considered as antibody responders with varied levels of IgG and measurable IgM levels in serum, although these levels had no obvious correlation with the incidence or severity of meningoencephalitis [85]. The event was predominantly singular, but four patients had moderate or severe relapses. Most of the 
diagnosed cases presented with progressively increased confusion, headache, or lethargy. A high white blood cell count was detected in the cerebrospinal fluid (15 to 130 cells per $\mu \mathrm{l}$ ) with no signs of viral or bacterial infection. Twelve patients recovered to baseline status, and six patients continued to decline cognitively after the event.

Whilst a report on the 1-year clinical follow-up of a subset of 30 immunized AD patients from the phase IIa study suggested evidence of a reduced cognitive decline in patients who generated antibodies against $\beta$-amyloid [86], a 1-year follow-up of all patients showed no significant findings on clinical outcomes [87]. Furthermore, long-term (5 year) clinical and neuropathological follow-up of patients from the phase I trial showed that despite an antibody response, no overall positive effect on cognition was observed - the decline was similar to control patients [88]. In the whole cohort, there was no evidence of improved survival or of an improvement in the time to severe dementia.

Neuropathological reports on patients from the phase I and IIa studies all reported similar findings [88-93]. A significant reduction in $\mathrm{A} \beta$ pathology was evident, as well as resolution of some tau features (dystrophic neurites). The remaining $A \beta$ plaques showed dense core morphology and patchy distribution in the affected brain areas. No effect on NFTs was found. Most cases also reported signs of $A \beta$ particles within microglia, suggesting immunisation-induced $A \beta$ phagocytosis.

A comparison between neuropathological and clinical data in eight of the immunised patients from the phase I study showed that the degree of plaque removal correlated with the mean antibody response attained during the treatment study period [88]. However, these patients had severe end stage dementia before death, including those with virtually complete plaque removal, with the exception of one patient, who had died very shortly after their first immunisation dose (due to a cause unrelated to the immunisation treatment). The conclusion was that although immunisation with $A \beta$ resulted in clearance of amyloid plaques in patients with $\mathrm{AD}$, this clearance did not prevent progressive neurodegeneration.

The initial $\mathrm{A} \beta$ immunisation clinical trials therefore had mixed results and the information obtained has been influencing the development of subsequent trials. Several clinical trials involving active and passive immunisation in $\mathrm{AD}$ are currently underway [94]. These include early phase active immunisation studies aimed at the carboxyl terminus of $A \beta$ (amino acids 1 to 6; Novartis), passive immunisation using antibodies against the amino terminus (amino acids 33 to 40; Pfizer) and the use of intravenous immunoglobulin (Baxter Bioscience). Later phase passive immunisation studies include the use of antibodies to the mid-region of $A \beta$ (amino acids 13 to 28; Lilly) and to the amino terminus (Bapineuzumab; amino acids 1 to 5; Elan). The latter has now entered a large phase III clinical trial with initial findings in an earlier study suggesting a beneficial effect for subjects not carrying the APOE $\varepsilon 4$ allele.

\section{Conclusion}

Research into the inflammation in $\mathrm{AD}$ so far has demonstrated the complexity of the mechanisms involved, which interact with each other in multiple ways. This web of interactions makes it difficult to isolate any particular inflammatory process, element or cell and pinpoint its individual role in the progress of the disease. Immunisation as one of the $\mathrm{AD}$ treatment approaches has led to an increased interest in the immune processes associated with this disease and highlighted their role in $\mathrm{AD}$ pathogenesis. The ability to modulate the immune system by active immunisation to generate anti-A $\beta$ antibodies and stimulate clearance of amyloid plaques underlined the potentially beneficial effect that the immune system can have on the pathology of the disease. The inflammatory response side-effect developed by some immunised patients pointed to the complexity of the immune processes acting in the brain and their potential for harmful effects. Microglia, as the main representative of the immune system in the CNS, play an important role in both of these effects. Their mechanism of action in AD pathogenesis and in the context of $A \beta$ immunisation is still not clear. This review aimed to highlight the necessity of approaching current and future research into AD from multiple directions, and the importance of addressing neuro-immune interactions involved in the whole course of the disease when devising potential treatment strategies.

\section{Abbreviations}

$\mathrm{A} \beta=$ amyloid beta; $\mathrm{AD}=$ Alzheimer's disease; $\mathrm{APOE}=$ apolipoprotein $\mathrm{E} ; \mathrm{CNS}=$ central nervous system; IL = interleukin; NFT = neurofibrillary tangle; NSAID = non-steroidal anti-inflammatory drug; TNF = tumour necrosis factor.

\section{Acknowledgements}

EZ, JARN, CH, and DB are funded by the Alzheimer's Research Trust (ART/ PG2006/4)

\section{Author details}

'Division of Clinical Neurosciences, School of Medicine, University of Southampton, Mailpoint 806, Level D, South Pathology Block, Southampton General Hospital, Southampton, SO16 6YD, UK

${ }^{2}$ Neuropathology, Department of Cellular Pathology, Southampton University Hospitals NHS Trust, Southampton, SO16 6YD, UK

${ }^{3}$ Institute for Ageing and Health, Campus for Ageing and Vitality, Newcastle University, Newcastle upon Tyne NE4 5PL, UK

${ }^{4}$ Memory Assessment Centre, Moorgreen Hospital, Hampshire Partnership Trust, Southampton, SO30 3JB, UK

Competing interests

The authors declare that they have no competing interests.

Published: 22 January 2010 


\section{References}

1. Rozemuller JM, Eikelenboom P, Stam FC: Role of microglia in plaque formation in senile dementia of the Alzheimer type. An immunohistochemical study. Virchows Arch B Cell Pathol Incl Mol Pathol 1986, 51:247-254

2. Rogers J, Luber-Narod J, Styren SD, Civin WH: Expression of immune systemassociated antigens by cells of the human central nervous system: relationship to the pathology of Alzheimer's disease. Neurobiol Aging 1988, 9:339-349.

3. Griffin WS, Stanley LC, Ling C, White L, MacLeod V, Perrot $L$, White $r C$ L, Araoz C: Brain interleukin 1 and S-100 immunoreactivity are elevated in Down syndrome and Alzheimer disease. Proc Natl Acad Sci U S A 1989, 86:7611-7615

4. Kalaria RN: Microglia and Alzheimer's disease. Curr Opin Hematol 1999, 6:15-24.

5. Akiyama H, Barger S, Barnum S, Bradt B, Bauer J, Cole GM, Cooper NR, Eikelenboom P, Emmerling M, Fiebich BL, Finch CE, Frautschy S, Griffin WS Hampel H, Hull M, Landreth G, Lue L, Mrak R, Mackenzie IR, McGeer PL, O'Banion MK, Pachter J, Pasinetti G, Plata-Salaman C, Rogers J, Rydel R, Shen Y, Streit W, Strohmeyer R, Tooyoma I, et al.: Inflammation and Alzheimer's disease. Neurobio/ Aging 2000, 21:383-421

6. Eikelenboom P, Veerhuis R, Scheper W, Rozemuller AJ, van Gool WA, Hoozemans JJ: The significance of neuroinflammation in understanding Alzheimer's disease. J Neural Transm 2006, 113:1685-1695.

7. Griffin WS: Inflammation and neurodegenerative diseases. Am J Clin Nutr 2006, 83:470S-474S

8. Shepherd CE, Thiel E, McCann H, Harding AJ, Halliday GM: Cortical inflammation in Alzheimer disease but not dementia with Lewy bodies. Arch Neurol 2000, 57:817-822

9. Arnaud L, Robakis NK, Figueiredo-Pereira ME: It may take inflammation, phosphorylation and ubiquitination to 'tangle' in Alzheimer's disease. Neurodegener Dis 2006, 3:313-319.

10. Gorlovoy $\mathrm{P}$, Larionov S, Pham TT, Neumann H: Accumulation of tau induced in neurites by microglial proinflammatory mediators. Faseb J 2009, 23:2502-2513

11. Breitner JC, Gau BA, Welsh KA, Plassman BL, McDonald WM, Helms MJ, Anthony JC: Inverse association of anti-inflammatory treatments and Alzheimer's disease: initial results of a co-twin control study. Neurology 1994, 44:227-232.

12. Rich JB, Rasmusson DX, Folstein MF, Carson KA, Kawas C, Brandt J: Nonsteroidal anti-inflammatory drugs in Alzheimer's disease. Neurology 1995, 45:51-55.

13. Beard CM, Waring SC, O'Brien PC, Kurland LT, Kokmen E: Nonsteroidal antiinflammatory drug use and Alzheimer's disease: a case-control study in Rochester, Minnesota, 1980 through 1984. Mayo Clin Proc 1998, 73:951-955.

14. Landi F, Cesari M, Onder G, Russo A, Torre S, Bernabei R: Non-steroidal antiinflammatory drug (NSAID) use and Alzheimer disease in communitydwelling elderly patients. Am J Geriatr Psychiatry 2003, 11:179-185.

15. Szekely CA, Thorne JE, Zandi PP, Ek M, Messias E, Breitner JC, Goodman SN: Nonsteroidal anti-inflammatory drugs for the prevention of Alzheimer's disease: a systematic review. Neuroepidemiology 2004, 23:159-169.

16. in $t^{\prime}$ Veld BA, Ruitenberg A, Hofman A, Launer LJ, van Duijn CM, Stijnen T, Breteler MM, Stricker BH: Nonsteroidal antiinflammatory drugs and the risk of Alzheimer's disease. N Engl J Med 2001, 345:1515-1521.

17. Zandi PP, Anthony JC, Hayden KM, Mehta K, Mayer L, Breitner JC: Reduced incidence of $A D$ with NSAID but not $\mathrm{H} 2$ receptor antagonists: the Cache County Study. Neurology 2002, 59:880-886.

18. McGeer PL, McGeer EG: NSAIDs and Alzheimer disease: epidemiological, animal model and clinical studies. Neurobiol Aging 2007, 28:639-647.

19. Bacher M, Dodel R, Aljabari B, Keyvani K, Marambaud P, Kayed R, Glabe C, Goertz N, Hoppmann A, Sachser N, Klotsche J, Schnell S, Lewejohann L, Al-Abed Y: CNI-1493 inhibits Abeta production, plaque formation, and cognitive deterioration in an animal model of Alzheimer's disease. J Exp Med 2008, 205:1593-1599.

20. Stewart WF, Kawas C, Corrada M, Metter EJ: Risk of Alzheimer's disease and duration of NSAID use. Neurology 1997, 48:626-632.

21. McGeer EG, McGeer PL: The importance of inflammatory mechanisms in Alzheimer disease. Exp Gerontol 1998, 33:371-378.

22. Eikelenboom $P$, Veerhuis $R$ : The importance of inflammatory mechanisms for the development of Alzheimer's disease. Exp Gerontol 1999, 34:453-461.

23. Jantzen PT, Connor KE, DiCarlo G, Wenk GL, Wallace JL, Rojiani AM, Coppola D,
Morgan D, Gordon MN: Microglial activation and beta-amyloid deposit reduction caused by a nitric oxide-releasing nonsteroidal antiinflammatory drug in amyloid precursor protein plus presenilin-1 transgenic mice. J Neurosci 2002, 22:2246-2254

24. Nicoll JA, Mrak RE, Graham DI, Stewart J, Wilcock G, MacGowan S, Esiri MM, Murray LS, Dewar D, Love S, Moss T, Griffin WS: Association of interleukin-1 gene polymorphisms with Alzheimer's disease. Ann Neurol 2000, 47:365-368.

25. Culpan D, MacGowan SH, Ford JM, Nicoll JA, Griffin WS, Dewar D, Cairns NJ, Hughes A, Kehoe PG, Wilcock GK: Tumour necrosis factor-alpha gene polymorphisms and Alzheimer's disease. Neurosci Lett 2003, 350:61-65.

26. Hayes A, Green EK, Pritchard A, Harris JM, Zhang Y, Lambert JC, Chartier-Harlin MC, Pickering-Brown SM, Lendon CL, Mann DM: A polymorphic variation in the interleukin $1 \mathrm{~A}$ gene increases brain microglial cell activity in Alzheimer's disease. J Neurol Neurosurg Psychiatry 2004, 75:1475-1477.

27. Bertram L, McQueen MB, Mullin K, Blacker D, Tanzi RE: Systematic metaanalyses of Alzheimer disease genetic association studies: the AlzGene database. Nat Genet 2007, 39:17-23.

28. Horsburgh K, McCarron MO, White F, Nicoll JA: The role of apolipoprotein E in Alzheimer's disease, acute brain injury and cerebrovascular disease: evidence of common mechanisms and utility of animal models. Neurobiol Aging 2000, 21:245-255.

29. Egensperger R, Kosel S, von Eitzen U, Graeber MB: Microglial activation in Alzheimer disease: association with APOE genotype. Brain Pathol 1998, 8:439-447.

30. Rogers J, Shen Y: A perspective on inflammation in Alzheimer's disease. Ann N Y Acad Sci 2000, 924:132-135.

31. Perry VH, Cunningham C, Holmes C: Systemic infections and inflammation affect chronic neurodegeneration. Nat Rev Immuno/ 2007, 7:161-167.

32. Engelhart MJ, Geerlings MI, Meijer J, Kiliaan A, Ruitenberg A, van Swieten JC, Stijnen T, Hofman A, Witteman JC, Breteler MM: Inflammatory proteins in plasma and the risk of dementia: the rotterdam study. Arch Neurol 2004, 61:668-672.

33. van Exel E, de Craen AJ, Remarque EJ, Gussekloo J, Houx P, Bootsma-van der Wiel A, Frolich M, Macfarlane PW, Blauw GJ, Westendorp RG: Interaction of atherosclerosis and inflammation in elderly subjects with poor cognitive function. Neurology 2003, 61:1695-1701.

34. Eikelenboom P, Hack CE, Rozemuller JM, Stam FC: Complement activation in amyloid plaques in Alzheimer's dementia. Virchows Arch B Cell Pathol Ind Mol Pathol 1989, 56:259-262

35. Haga S, Akai K, Ishii T: Demonstration of microglial cells in and around senile (neuritic) plaques in the Alzheimer brain. An immunohistochemical study using a novel monoclonal antibody. Acta Neuropatho/ 1989, 77:569-575.

36. McGeer PL, Akiyama H, Itagaki S, McGeer EG: Immune system response in Alzheimer's disease. Can J Neuro/ Sci 1989, 16:516-527.

37. Perlmutter LS, Scott SA, Barron E, Chui HC: MHC class II-positive microglia in human brain: association with Alzheimer lesions. J Neurosci Res 1992, 33:549-558.

38. Strauss S, Bauer J, Ganter U, Jonas U, Berger M, Volk B: Detection of interleukin-6 and alpha 2-macroglobulin immunoreactivity in cortex and hippocampus of Alzheimer's disease patients. Lab Invest 1992, 66:223-230.

39. Lanzrein AS, Johnston CM, Perry VH, Jobst KA, King EM, Smith AD: Longitudinal study of inflammatory factors in serum, cerebrospinal fluid, and brain tissue in Alzheimer disease: interleukin-1 beta, interleukin-6, interleukin-1 receptor antagonist, tumor necrosis factor-alpha, the soluble tumor necrosis factor receptors I and II, and alpha1-antichymotrypsin. Alzheimer Dis Assoc Disord 1998, 12:215-227.

40. Overmyer M, Helisalmi S, Soininen H, Laakso M, Riekkinen S P, Alafuzoff I: Reactive microglia in aging and dementia: an immunohistochemical study of postmortem human brain tissue. Acta Neuropathol 1999, 97:383-392.

41. Lue LF, Brachova L, Civin WH, Rogers J: Inflammation, A beta deposition, and neurofibrillary tangle formation as correlates of Alzheimer's disease neurodegeneration. J Neuropathol Exp Neurol 1996, 55:1083-1088.

42. Edison P, Archer HA, Gerhard A, Hinz R, Pavese N, Turkheimer FE, Hammers A Tai YF, Fox N, Kennedy A, Rossor M, Brooks DJ: Microglia, amyloid, and cognition in Alzheimer's disease: An [11C](R)PK11195-PET and [11C]PIBPET study. Neurobiol Dis 2008, 32:412-419.

43. Galea I, Bechmann I, Perry VH: What is immune privilege (not)? Trends Immunol 2007, 28:12-18. 
44. Fiala M, Liu PT, Espinosa-Jeffrey A, Rosenthal MJ, Bernard G, Ringman JM, Sayre J, Zhang L, Zaghi J, Dejbakhsh S, Chiang B, Hui J, Mahanian M, Baghaee A, Hong P, Cashman J: Innate immunity and transcription of MGAT-III and Toll-like receptors in Alzheimer's disease patients are improved by bisdemethoxycurcumin. Proc Natl Acad Sci U S A 2007, 104:12849-12854.

45. Aravalli RN, Peterson PK, Lokensgard JR: Toll-like receptors in defense and damage of the central nervous system. J Neuroimmune Pharmaco/ 2007, 2:297-312.

46. Richard KL, Filali M, Prefontaine P, Rivest S: Toll-like receptor 2 acts as a natural innate immune receptor to clear amyloid beta 1-42 and delay the cognitive decline in a mouse model of Alzheimer's disease. J Neurosci 2008, 28:5784-5793

47. Morgan D, Gordon MN, Tan J, Wilcock D, Rojiani AM: Dynamic complexity of the microglial activation response in transgenic models of amyloid deposition: implications for Alzheimer therapeutics. J Neuropathol Exp Neuro/ 2005, 64:743-753.

48. Streit WJ: Microglia and Alzheimer's disease pathogenesis. J Neurosci Res 2004, 77:1-8.

49. Tooyama I, Kimura H, Akiyama H, MCGeer PL: Reactive microglia express class I and class II major histocompatibility complex antigens in Alzheimer's disease. Brain Res 1990, 523:273-280.

50. Yang F, Sun X, Beech W, Teter B, Wu S, Sigel J, Vinters HV, Frautschy SA, Cole GM: Antibody to caspase-cleaved actin detects apoptosis in differentiated neuroblastoma and plaque-associated neurons and microglia in Alzheimer's disease. Am J Pathol 1998, 152:379-389.

51. Hyman BT, Smith C, Buldyrev I, Whelan C, Brown H, Tang MX, Mayeux R: Autoantibodies to amyloid-beta and Alzheimer's disease. Ann Neurol 2001, 49:808-810

52. Xu S, Gaskin F: Increased incidence of anti-beta-amyloid autoantibodies secreted by Epstein-Barr virus transformed B cell lines from patients with Alzheimer's disease. Mech Ageing Dev 1997, 94:213-222.

53. Monsonego A, Zota V, Karni A, Krieger Jl, Bar-Or A, Bitan G, Budson AE, Sperling R, Selkoe DJ, Weiner HL: Increased T cell reactivity to amyloid beta protein in older humans and patients with Alzheimer disease. J Clin Invest 2003, 112:415-422.

54. Simard AR, Soulet D, Gowing G, Julien JP, Rivest S: Bone marrow-derived microglia play a critical role in restricting senile plaque formation in Alzheimer's disease. Neuron 2006, 49:489-502.

55. El Khoury J, Toft M, Hickman SE, Means TK, Terada K, Geula C, Luster AD: Ccr2 deficiency impairs microglial accumulation and accelerates progression of Alzheimer-like disease. Nat Med 2007, 13:432-438.

56. Town T, Laouar Y, Pittenger C, Mori T, Szekely CA, Tan J, Duman RS, Flavell RA: Blocking TGF-beta-Smad2/3 innate immune signaling mitigates Alzheimer-like pathology. Nat Med 2008, 14:681-687.

57. Boche D, Cunningham C, Docagne F, Scott H, Perry VH: TGFbeta1 regulates the inflammatory response during chronic neurodegeneration. Neurobiol Dis 2006, 22:638-650.

58. Combrinck MI, Perry VH, Cunningham C: Peripheral infection evokes exaggerated sickness behaviour in pre-clinical murine prion disease. Neuroscience 2002, 112:7-11.

59. Rogers J, Strohmeyer R, Kovelowski CJ, Li R: Microglia and inflammatory mechanisms in the clearance of amyloid beta peptide. Glia 2002, 40:260-269.

60. Morgan D: Mechanisms of A beta plaque clearance following passive $A$ beta immunization. Neurodegener Dis 2005, 2:261-266.

61. Lim GP, Yang F, Chu T, Chen P, Beech W, Teter B, Tran T, Ubeda O, Ashe KH, Frautschy SA, Cole GM: Ibuprofen suppresses plaque pathology and inflammation in a mouse model for Alzheimer's disease. J Neurosci 2000, 20:5709-5714

62. Weggen S, Eriksen JL, Das P, Sagi SA, Wang R, Pietrzik CU, Findlay KA, Smith TE, Murphy MP, Bulter T, Kang DE, Marquez-Sterling N, Golde TE, Koo EH: A subset of NSAIDs lower amyloidogenic Abeta42 independently of cyclooxygenase activity. Nature 2001, 414:212-216.

63. Schenk D, Barbour R, Dunn W, Gordon G, Grajeda H, Guido T, Hu K, Huang J, Johnson-Wood K, Khan K, Kholodenko D, Lee M, Liao Z, Lieberburg I, Motter R, Mutter L, Soriano F, Shopp G, Vasquez N, Vandevert C, Walker S, Wogulis M, Yednock T, Games D, Seubert P: Immunization with amyloid-beta attenuates Alzheimer-disease-like pathology in the PDAPP mouse. Nature 1999, 400:173-177.

64. Janus C, Pearson J, McLaurin J, Mathews PM, Jiang Y, Schmidt SD, Chishti MA, Horne P, Heslin D, French J, Mount HT, Nixon RA, Mercken M, Bergeron C,
Fraser PE, St George-Hyslop P, Westaway D: A beta peptide immunization reduces behavioural impairment and plaques in a model of Alzheimer's disease. Nature 2000, 408:979-982

65. Bard F, Cannon C, Barbour R, Burke RL, Games D, Grajeda H, Guido T, Hu K, Huang J, Johnson-Wood K, Khan K, Kholodenko D, Lee M, Lieberburg I, Motter R, Nguyen M, Soriano F, Vasquez N, Weiss K, Welch B, Seubert P, Schenk D, Yednock T: Peripherally administered antibodies against amyloid beta-peptide enter the central nervous system and reduce pathology in a mouse model of Alzheimer disease. Nat Med 2000, 6:916-919.

66. Morgan D, Diamond DM, Gottschall PE, Ugen KE, Dickey C, Hardy J, Duff K, Jantzen P, DiCarlo G, Wilcock D, Connor K, Hatcher J, Hope C, Gordon M, Arendash GW: A beta peptide vaccination prevents memory loss in an animal model of Alzheimer's disease. Nature 2000, 408:982-985.

67. DeMattos RB, Bales KR, Cummins DJ, Dodart JC, Paul SM, Holtzman DM: Peripheral anti-A beta antibody alters CNS and plasma A beta clearance and decreases brain A beta burden in a mouse model of Alzheimer's disease. Proc Natl Acad Sci U S A 2001, 98:8850-8855.

68. Sigurdsson EM, Scholtzova H, Mehta PD, Frangione B, Wisniewski T: Immunization with a nontoxic/nonfibrillar amyloid-beta homologous peptide reduces Alzheimer's disease-associated pathology in transgenic mice. Am J Pathol 2001, 159:439-447.

69. Bacskai BJ, Kajdasz ST, McLellan ME, Games D, Seubert P, Schenk D, Hyman BT: Non-Fc-mediated mechanisms are involved in clearance of amyloid-beta in vivo by immunotherapy. J Neurosci 2002, 22:7873-7878.

70. Dodart JC, Bales KR, Gannon KS, Greene SJ, DeMattos RB, Mathis C, DeLong CA, Wu S, Wu X, Holtzman DM, Paul SM: Immunization reverses memory deficits without reducing brain Abeta burden in Alzheimer's disease model. Nat Neurosci 2002, 5:452-457.

71. Das P, Howard V, Loosbrock N, Dickson D, Murphy MP, Golde TE: Amyloidbeta immunization effectively reduces amyloid deposition in FcRgamma-/- knock-out mice. J Neurosci 2003, 23:8532-8538.

72. Wilcock DM, DiCarlo G, Henderson D, Jackson J, Clarke K, Ugen KE, Gordon MN, Morgan D: Intracranially administered anti-Abeta antibodies reduce beta-amyloid deposition by mechanisms both independent of and associated with microglial activation. J Neurosci 2003, 23:3745-3751.

73. Wilcock DM, Rojiani A, Rosenthal A, Levkowitz G, Subbarao S, Alamed J, Wilson D, Wilson N, Freeman MJ, Gordon MN, Morgan D: Passive amyloid immunotherapy clears amyloid and transiently activates microglia in a transgenic mouse model of amyloid deposition. J Neurosci 2004 , 24:6144-6151.

74. Brendza RP, Bacskai BJ, Cirrito JR, Simmons KA, Skoch JM, Klunk WE, Mathis CA, Bales KR, Paul SM, Hyman BT, Holtzman DM: Anti-Abeta antibody treatment promotes the rapid recovery of amyloid-associated neuritic dystrophy in PDAPP transgenic mice. J Clin Invest 2005, 115:428-433.

75. Asuni AA, Boutajangout A, Scholtzova H, Knudsen E, Li YS, Quartermain D, Frangione B, Wisniewski T, Sigurdsson EM: Vaccination of Alzheimer's model mice with Abeta derivative in alum adjuvant reduces Abeta burden without microhemorrhages. Eur J Neurosci 2006, 24:2530-2542.

76. Wilcock DM, Munireddy SK, Rosenthal A, Ugen KE, Gordon MN, Morgan D: Microglial activation facilitates Abeta plaque removal following intracranial anti-Abeta antibody administration. Neurobiol Dis 2004, 15:11-20.

77. Sigurdsson EM, Wisniewski T, Frangione B: A safer vaccine for Alzheimer's disease? Neurobiol Aging 2002, 23:1001-1008.

78. Oddo S, Caccamo A, Shepherd JD, Murphy MP, Golde TE, Kayed R, Metherate R, Mattson MP, Akbari Y, LaFerla FM: Triple-transgenic model of Alzheimer's disease with plaques and tangles: intracellular Abeta and synaptic dysfunction. Neuron 2003, 39:409-421.

79. Billings LM, Oddo S, Green KN, McGaugh JL, LaFerla FM: Intraneuronal Abeta causes the onset of early Alzheimer's disease-related cognitive deficits in transgenic mice. Neuron 2005, 45:675-688.

80. Oddo S, Billings L, Kesslak JP, Cribbs DH, LaFerla FM: Abeta immunotherapy leads to clearance of early, but not late, hyperphosphorylated tau aggregates via the proteasome. Neuron 2004, 43:321-332.

81. Oddo S, Vasilevko V, Caccamo A, Kitazawa M, Cribbs DH, LaFerla FM: Reduction of soluble Abeta and tau, but not soluble Abeta alone ameliorates cognitive decline in transgenic mice with plaques and tangles. J Biol Chem 2006, 281:39413-39423.

82. Trouche SG, Asuni A, Rouland S, Wisniewski T, Frangione B, Verdier JM Sigurdsson EM, Mestre-Frances N: Antibody response and plasma Abeta1-40 levels in young Microcebus murinus primates immunized with 
Abeta1-42 and its derivatives. Vaccine 2009, 27:957-964.

83. Sigurdsson EM: Immunotherapy targeting pathological tau protein in Alzheimer's disease and related tauopathies. J Alzheimers Dis 2008, 15:157-168.

84. Bayer AJ, Bullock R, Jones RW, Wilkinson D, Paterson KR, Jenkins L, Millais SB, Donoghue $S$ : Evaluation of the safety and immunogenicity of synthetic Abeta42 (AN1792) in patients with AD. Neurology 2005, 64:94-101.

85. Orgogozo JM, Gilman S, Dartigues JF, Laurent B, Puel M, Kirby LC, Jouanny P, Dubois B, Eisner L, Flitman S, Michel BF, Boada M, Frank A, Hock C: Subacute meningoencephalitis in a subset of patients with AD after Abeta42 immunization. Neurology 2003, 61:46-54.

86. Hock C, Konietzko U, Streffer JR, Tracy J, Signorell A, Muller-Tillmanns B, Lemke U, Henke K, Moritz E, Garcia E, Wollmer MA, Umbricht D, de Quervain D」, Hofmann M, Maddalena A, Papassotiropoulos A, Nitsch RM: Antibodies against beta-amyloid slow cognitive decline in Alzheimer's disease. Neuron 2003, 38:547-554.

87. Gilman S, Koller M, Black RS, Jenkins L, Griffith SG, Fox NC, Eisner L, Kirby L, Rovira MB, Forette F, Orgogozo JM: Clinical effects of Abeta immunization (AN1792) in patients with AD in an interrupted trial. Neurology 2005, 64:1553-1562.

88. Holmes C, Boche D, Wilkinson D, Yadegarfar G, Hopkins V, Bayer A, Jones RW, Bullock R, Love S, Neal JW, Zotova E, Nicoll JA: Long-term effects of Abeta42 immunisation in Alzheimer's disease: follow-up of a randomised, placebocontrolled phase I trial. Lancet 2008, 372:216-223.

89. Nicoll JA, Wilkinson D, Holmes C, Steart P, Markham H, Weller RO: Neuropathology of human Alzheimer disease after immunization with amyloid-beta peptide: a case report. Nat Med 2003, 9:448-452.

90. Ferrer I, Boada Rovira M, Sanchez Guerra ML, Rey MJ, Costa-Jussa F: Neuropathology and pathogenesis of encephalitis following amyloid-beta immunization in Alzheimer's disease. Brain Pathol 2004, 14:11-20.

91. Masliah E, Hansen L, Adame A, Crews L, Bard F, Lee C, Seubert P, Games D, Kirby L, Schenk D: Abeta vaccination effects on plaque pathology in the absence of encephalitis in Alzheimer disease. Neurology 2005, 64:129-131.
92. Nicoll JA, Barton E, Boche D, Neal JW, Ferrer I, Thompson P, Vlachouli C, Wilkinson D, Bayer A, Games D, Seubert P, Schenk D, Holmes C: Abeta species removal after abeta42 immunization. J Neuropathol Exp Neurol 2006, 65:1040-1048.

93. Bombois S, Maurage CA, Gompel M, Deramecourt V, Mackowiak-Cordoliani MA, Black RS, Lavielle R, Delacourte A, Pasquier F: Absence of beta-amyloid deposits after immunization in Alzheimer disease with Lewy body dementia. Arch Neurol 2007, 64:583-587.

94. Wisniewski T, Konietzko U: Amyloid-beta immunisation for Alzheimer's disease. Lancet Neurol 2008, 7:805-811.

95. Parachikova A, Agadjanyan MG, Cribbs DH, Blurton-Jones M, Perreau V, Rogers J, Beach TG, Cotman CW: Inflammatory changes parallel the early stages of Alzheimer disease. Neurobiol Aging 2007, 28:1821-1833.

96. Ishii T, Haga S: Immuno-electron-microscopic localization of complements in amyloid fibrils of senile plaques. Acta Neuropathol 1984, 63:296-300.

97. Yasojima K, Schwab C, McGeer EG, McGeer PL: Up-regulated production and activation of the complement system in Alzheimer's disease brain. Am J Pathol 1999, 154:927-936.

98. Bonotis K, Krikki E, Holeva V, Aggouridaki C, Costa V, Baloyannis S: Systemic immune aberrations in Alzheimer's disease patients. J Neuroimmuno/ 2007, 193:183-187.

99. Fiala M, Lin J, Ringman J, Kermani-Arab V, Tsao G, Patel A, Lossinsky AS, Graves MC, Gustavson A, Sayre J, Sofroni E, Suarez T, Chiappelli F, Bernard G: Ineffective phagocytosis of amyloid-beta by macrophages of Alzheimer's disease patients. J Alzheimers Dis 2005, 7:221-232; discussion 255-262.

doi:10.1186/alzrt24

Cite this article as: Zotova E, et al.: Inflammation in Alzheimer's disease: relevance to pathogenesis and therapy. Alzheimer's Research \& Therapy 2010, 2:1. 